\title{
Analysis on the operation characteristics of the denitration facilities utilized in coal-fired power plants of a province in Southern China
}

\author{
Yongjin Liao ${ }^{1, a}$, Yuexi Yu ${ }^{1, b}$ and Ye Wang ${ }^{2, c}$ \\ ${ }^{1}$ Electric Power Research Institute of Guangdong Power Grid Corporation ,Guangzhou510060, \\ China;
}

${ }^{2}$ Bright Consult (Beijing) Co. Ltd.,Beijing 100028,China

alyj23455@163.com, ${ }^{b} 952374163 @ q q . c o m,{ }^{c}$ fanjunhui1026@163.com

Keywords: coal-fired unit,denitration facilities,operation.

\begin{abstract}
This paper firstly introduces the capacity,proprtion and type distribution for the denitration facilities utilized in a province in Southern China,and then analyzes the impact of the situation that the SCR exit operation in equipment fault and low smoke temperature under low load combined with the power plant de NOx equipment running status statistics. The data showed that the annealing time in low temperature for SCR denitrification facility account for $99.7 \%$ of the total exit operation time, which has become a major problem of SCR denitration facilities operation. Finally,in order to solve this problem, the suggestion for the improvement of heating surface transformation in the boiler is put forward to improve the load adaptability of SCR denitrification system.
\end{abstract}

\section{Introduction}

According to the data provided by the Internal Federation of Electric Power Enterprises,a large amount of coal has been burning to generate electricity.Up to the December in 2011, the National power generation capacity has reached $1.06 \times 10^{9} \mathrm{~kW}$, of which the thermal power is $7.7 \times 10^{8} \mathrm{~kW}$, accounting for $72.6 \%$ of the national total installed , and the thermal power generating capacity accounts for about $82.4 \%$ of the total power generation capacity.Besides, the form of the thermal power is almost coal-fired power generation, and other forms still account for less than $0.1 \%$ of the total generating capacity, Which consumes about 18.2 tons of the raw coal in over $6000 \mathrm{kw}$ of the coal-fired plants[1-2].However,pollutants generated by the coal is the main source of atmospheric pollutants.According to the data provided by the Internal Environmental Monitoring Station, the total amount of NOx emissions in home was $2.4 \times 10^{7} \mathrm{t}$ in $2011[3]$, of which was $1.73 \times 10^{8}$ from the industrial,but the thermal power industry in the process of the NOx emission accounted for more than half of the industrial .Therefore, it is necessary to take measures to curb the increasing momentum and gradually reduce the NOX emissions .Take the internal as an example, from the beginning of January 1 th in 2012, atmospheric pollutant discharge standard for the fossil fired power plant in GB 13223-2011, Regulating the limits of the nitrogen oxide emission from $450 \mathrm{mg} / \mathrm{m} 3$ to $100 \mathrm{mg} / \mathrm{m} 3$ for the new units and $200 \mathrm{mg} / \mathrm{m} 3$ for the one in service, has been carried out and the "economic and social development in national five year plan"adopted the fourth National People's Congress of the eleven meeting in March 2011,which clearly put forward the nitrogen oxide emission reduction 10\% of the binding targets in the Twelfth Five Year[4].

Since the beginning of the Eleventh Five Year, the state has strengthened the management of pollutant emissions, requiring the power generation enterprises to carry out denitrification transformation. With the denitration facilities utilized in coal-fired plant, the complexity of the operation of the unit would be added,which brings new problems of the unit in safe and stable operation[5-6].Especially in recent years, this influence has become more and more serious with the more strict environmental standards, which will to increase the uncertainty of the whole system.Therefore,this paper firstly introduces the denitration facilities utilized in a province in Southern China,and then analyzes statistically the operation status from 2012 to 2014 combined with the power plant de-NOx equipment running status statistics and the impact of the situation that the 
SCR exit operation in equipment fault and low smoke temperature under low load combined with the fault case in operation..

\section{The overview of denitrification facilities for coal fired power plant in a province in Southern China}

The Summary of the denitrification facilities for 10 coal fired power plants in a province in Southern China is summarized in Table 1 。 As is shown in Table 1, the total capacity of generating unit accounts for $93.8 \%$ of the all installed capacity of the coal-fired power plants in a province in Southern China.There are ten 600MW, eighteen 300MW and two 200MW among the units, which respectively accounts for $47.7 \%, 42.9 \%, 3.2 \%$ of the total capacity of the coal-fired power plants in a province in Southern China.Among which,the $600 \mathrm{MW}$ coal-fired generating units are all used W type in boiler and designed for burning anthracite, and the $300 \mathrm{MW}$ coal-fired generating units are all used the subcritical pressure boilers, of which is twelve tangential firing boilers and six circulating fluidized bed boilers, and designed for burning lignite or bituminous coal.

As is shown in Table 1,all units in coal-fired power plants with the SCR denitrification technology to reduce the NOX except circulating fluidized bed boilers with the SNCR denitrification technology.A classification map of denitrification device in the coal-fired plant in a province in Southern China in Figure 1.

Tab. 1 An overview on the Denitrification device of coal-fired power plant in Yunnan Province

\begin{tabular}{|c|c|c|c|c|c|c|c|c|c|c|}
\hline $\begin{array}{l}\text { Serial } \\
\text { number }\end{array}$ & Unit type & $\begin{array}{c}\text { Furnace type in } \\
\text { Boiler }\end{array}$ & $\begin{array}{c}\text { Peak load } \\
(\%)\end{array}$ & $\begin{array}{l}\text { Denitrificat } \\
\text { on proces؛ }\end{array}$ & $\begin{array}{c}\text { Design of entry } \\
\text { NOx } \\
\left(\mathrm{mg} / \mathrm{Nm}^{3}\right)\end{array}$ & $\begin{array}{c}\text { Design of } \\
\text { efficiency } \\
(\%)\end{array}$ & $\begin{array}{c}\text { Design of } \\
\text { ammonia } \\
\text { escape (ppm) }\end{array}$ & $\begin{array}{l}\text { Operating } \\
\text { temperature }^{\mathrm{p}} \\
\left({ }^{\circ} \mathrm{C}\right)\end{array}$ & $\begin{array}{l}\text { perating loar } \\
\qquad \%)\end{array}$ & Operation time \\
\hline 1 & $\begin{array}{c}4 * 600 \mathrm{MW} \text { in } \\
\text { subcritical }\end{array}$ & W 型 & $\begin{array}{l}\geq \\
60.0\end{array}$ & SCR & 1100 & 81.0 & $\leq 3$ & $\begin{array}{c}340 \sim \\
420\end{array}$ & $\underset{63.3}{\geq}$ & $\begin{array}{c}\text { 2013-6 } \\
\text { 至 } \\
2014-11\end{array}$ \\
\hline 2 & $\begin{array}{l}2 * 600 \mathrm{MW} \text { in } \\
\text { subcritical }\end{array}$ & $\mathrm{W}$ 型 & - & SCR & $\begin{array}{c}1200 / \\
536\end{array}$ & $83.3 / 80.0$ & $\leq 3$ & $\begin{array}{c}333 \sim \\
430 / \\
310 \sim \\
425\end{array}$ & $\underset{55.0}{\geq}$ & $\begin{array}{c}2009-9 \text { 至 } \\
2013-12\end{array}$ \\
\hline 3 & $\begin{array}{l}2 * 600 \mathrm{MW} \text { in } \\
\text { supercritical }\end{array}$ & W 型 & $\begin{array}{l}\geq \\
60.0\end{array}$ & SCR & 1100 & 82.0 & $\leq 2.28$ & $\begin{array}{l}305 \sim \\
430\end{array}$ & $\underset{60.0}{\geq}$ & $\begin{array}{c}2012-7 \text { 至 } \\
2012-12\end{array}$ \\
\hline 4 & $\begin{array}{l}2 * 600 \mathrm{MW} \text { in } \\
\text { supercritica }\end{array}$ & $\mathrm{W}$ 型 & $\begin{array}{l}\geq \\
60.0\end{array}$ & SCR & 1100 & 80.0 & $\leq 3$ & $\begin{array}{c}380 \sim \\
420\end{array}$ & $\underset{50.0}{\geq}$ & $\begin{array}{l}\text { 2012-1 至 } \\
\text { 2012-3 }\end{array}$ \\
\hline 5 & $\begin{array}{c}4 * 300 \mathrm{MW} \text { in } \\
\text { subcritical }\end{array}$ & $\begin{array}{l}\text { tangential } \\
\text { firing }\end{array}$ & $\underset{53.3}{\geq}$ & SCR & 500 & 75.0 & $\leq 3$ & $\begin{array}{l}310 \sim \\
420\end{array}$ & $\begin{array}{l}\geq 53.3 / \\
58.3\end{array}$ & $\begin{array}{c}\text { 2013-10 至 } \\
\text { 2014-12 }\end{array}$ \\
\hline 6 & $\begin{array}{c}6 * 300 \mathrm{MW} \text { in } \\
\text { subcritical }\end{array}$ & $\begin{array}{l}\text { tangential } \\
\text { firing }\end{array}$ & $\underset{56.6}{\geq}$ & SCR & 400 & 80.0 & $\leq 3$ & $\begin{array}{c}314 \sim \\
400\end{array}$ & $\geq 53.3$ & $\begin{array}{c}2013-3 \text { 至 } \\
2014-5\end{array}$ \\
\hline 7 & $\begin{array}{l}2 * 200 \mathrm{MW} \text { in } \\
\text { supercritica } \\
2 * 300 \mathrm{MW} \text { in } \\
\text { subcritical }\end{array}$ & $\begin{array}{c}\text { hexagonal } \\
\text { tangentially } \\
\text { fired/tangentia } \\
1 \text { firing } \\
\text { circulatin }\end{array}$ & $\begin{array}{c}\geq \\
45.0\end{array}$ & SCR & 650 & 85.0 & $\leq 3$ & $\begin{array}{c}325 \sim \\
420\end{array}$ & $\underset{45.0}{\geq}$ & $\begin{array}{c}2014-10 \text { 至 } \\
\text { 2014-11 }\end{array}$ \\
\hline 8 & $\begin{array}{c}2 * 300 \mathrm{MW} \text { in } \\
\text { subcritical }\end{array}$ & $\begin{array}{l}\mathrm{g} \\
\text { fluidized } \\
\text { bed } \\
\text { circulatin }\end{array}$ & $\underset{50.0}{\geq}$ & SNCR & 350 & 70.0 & $\leq 5$ & $750 \sim$ & $\underset{23.3}{\geq}$ & $\begin{array}{c}2014-12 \text { 至 } \\
\text { 2015-1 }\end{array}$ \\
\hline 9 & $\begin{array}{c}2 * 300 \mathrm{MW} \text { in } \\
\text { subcritical }\end{array}$ & $\begin{array}{c}\mathrm{g} \\
\text { fluidized } \\
\text { bed } \\
\text { circulatin }\end{array}$ & - & SNCR & 350 & 70.0 & $\leq 10$ & - & $\geq 33.3$ & $\begin{array}{c}2015-2 \text { 至 } \\
\text { 2015-3 }\end{array}$ \\
\hline 10 & $\begin{array}{c}2 * 300 \mathrm{MW} \text { in } \\
\text { subcritical }\end{array}$ & $\begin{array}{c}\mathrm{g} \\
\text { fluidized } \\
\text { bed }\end{array}$ & - & SNCR & 250 & 65.0 & $\leq 7.6$ & $\begin{array}{l}830 \sim \\
1000\end{array}$ & - & 2014-12 \\
\hline
\end{tabular}




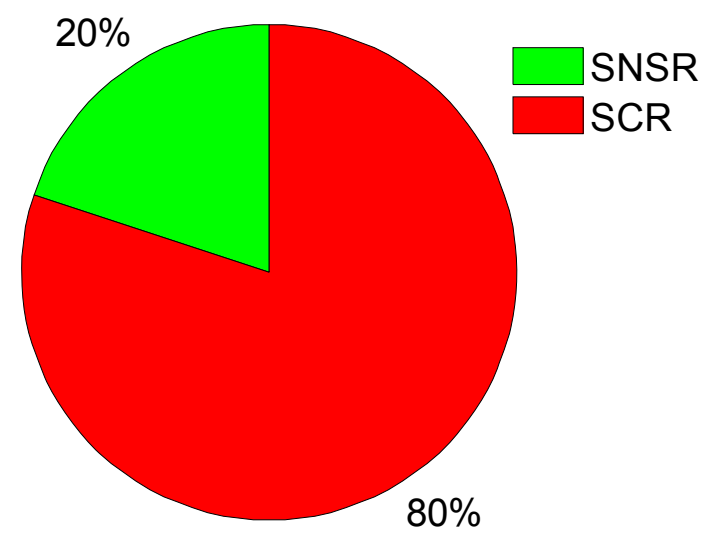

Fig.1 A classification map of denitrification device in the coal-fired plant in Yunnan province

As is shown in Figure 1,with the high denitration efficiency, the SCR technology are widely utilized in denitration facilities in a province in Southern China, which accounts for $80 \%$ of the total units.If so, the nitrogen oxide emission concentration of the unit is maintained under the $100 \mathrm{mg} / \mathrm{m} 3$, which can meet the current standards on the nitrogen oxide emission. For the conventional coal-fired units, with the low NOx burning technology, the nitrogen oxide emission concentration for boiler output is only maintained under the $400 \mathrm{mg} / \mathrm{m}_{3}$ [7], and if the discharge concentration in the unit reach the standard, the denitrification efficiency will need to reach at least $75 \%$.However,at present the SNCR technology is very difficult to meet the requirements. As is shown in Table 1, the efficiency of the design can reach more than $80 \%$ with the SCR technology, while the SNCR technology can reach at most $70 \%$.

As is also shown in Figure 1,the minimum operating temperature of SCR denitrification facilities is mainly distributed at $305 \sim 340^{\circ} \mathrm{C}$ and the maximum operating temperature of SCR denitrification facilities is mainly distributed at $400 \sim 430^{\circ} \mathrm{C}$, which is mainly determined by the reaction temperature of the catalyst.If the reaction temperature is too low, ammonium hydrogen sulfate will be generated, which will lead to the loss of the system; while if the reaction temperature is too high, it may cause the phase change of the catalyst materials, resulting in the degradation of the catalyst activity [8].According to the Figure 1,Through the lowest peaking load in plants contrast the minimum operation load of the design for the denitrification facilities, it is not difficult to find that 14 sets of SCR denitrification devices in the lowest operation load is less than or equal to the limit of the peak load regulation,which accounts for $63.6 \%$ of the total.However,for the SNCR denitrification facilities, the minimum operation load is lower than that of SCR combined with the feedback information from the plants,such as the $8 \#$ power plant $(23.3 \%)$ and $9(33.3 \%)$ power plant in the Figure 1.

According to the Figure 1,Comparing the design value of NOx in the inlet of the denitrification facilities for the variety of boiler types, the conclusion can be found that the NOx in W type boilers is the highest that the data is basically $1100 \sim 1200 \mathrm{mg} / \mathrm{Nm} 3$ except from the SCR denitrification device of the $2 \#$ boiler in the second plant; the quantity of the inlet NOX of the denitrification facilities in tangential firing boilers are basically $400 \sim 650 \mathrm{mg} / \mathrm{Nm} 3$ that next to in $\mathrm{W}$ type boilers, while the design value of NOx concentration of the SNCR denitrification device inthe circulating fluidized bed boilers is minimum, which is basically between $250 \sim 350 \mathrm{mg} / \mathrm{Nm} 3$. Therefore, according to the "air pollutant discharge standard in the thermal power plant" beginning to be carried out in January 1,2012, the design value of the SCR denitrification devices for the pulverized coal-fired boilers is $75 \sim 85 \%$, while in the SNCR for the circulating fluidized bed boilers is $65 \sim 70 \%$.

\section{Analysis on the operation of denitrification devices}

As is shown in Table 2, the operation situation of the denitrification facilities for above ten plants has been collected,which can be found that the denitrification rate of SNCR is lower, but the reliability is very high. Although the denitrification rate is high that generally more than $80 \%$, the case 
of annealing operation has increased significantly in the fault probability and low temperature.Furthermore, the exit operation of the SCR in low temperature when the unit load is relatively low is the main problem of the SCR operation.As is shown in Figure 2, in recent years, while the time of the SCR annealing operation for all units is only 87.5 hours because of all kinds of equipment fault, the exit operation time, due to the low temperature in lower load, has reached about 28332 hours, which has accounted for $99.7 \%$ of the situation of the SCR denitrification facilities exit operation and become the main problem of SCR devices operation..

Tab. 2 A statistical summary of the operating status for the NOx removal device of a province in Southern China

\begin{tabular}{|c|c|c|c|c|c|c|c|c|c|}
\hline $\begin{array}{l}\text { Seria } \\
\text { numb }\end{array}$ & & $\begin{array}{l}\text { ctual of expor } \\
\mathrm{NOx}\left(\mathrm{mg} / \mathrm{Nm}^{3}\right.\end{array}$ & $\begin{array}{l}\text { Average } \\
\text { efficienc } \\
y(\%)\end{array}$ & $\begin{array}{l}\text { Average } \\
\text { ammonia } \\
\text { escape(ppm } \\
\text { ) }\end{array}$ & $\begin{array}{c}\mathrm{O}_{2} / \mathrm{SO}_{3} \mathrm{Conv} \text { ' } \\
\text { rsion rate } \\
(\%)\end{array}$ & $\begin{array}{c}\text { pressure } \\
\text { drop in } \\
\text { System } \\
(\mathrm{Pa})\end{array}$ & $\begin{array}{l}\text { Minimum } \\
\text { operating } \\
\text { temperature }( \\
\left.{ }^{\circ} \mathrm{C}\right)\end{array}$ & $\begin{array}{l}\text { Annealing operation time } \\
(\text { in low temperature }(\mathrm{h})\end{array}$ & The types and times in the fault \\
\hline 1 & 1100 & 200 & 82.4 & 1.8 & 0.8 & 800 & 340 & - & 无 \\
\hline 2 & $\begin{array}{c}1329 / \\
1066\end{array}$ & $168 / 187$ & $\begin{array}{c}88.5 / 83 \\
.8\end{array}$ & $2.03 / 1.67$ & - & $170 / 320$ & $\begin{array}{l}340 / \\
340\end{array}$ & 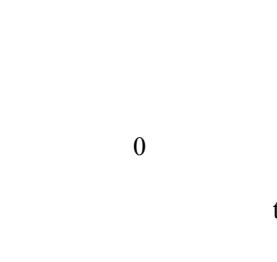 & $\begin{array}{l}\text { The fault of ammonia evaporator in } \\
\quad \# 2 \text { unit in } 2012 \text {, } \\
\text { The SCRexit operation period is } \\
3.58 \mathrm{~h} \text { in a unitat one time. } \\
\text { The leakage of ammonia area in } \# 2 \\
\text { unit in } 2013 \text {, } \\
\text { the SCRexit operation period is } 3.58 \mathrm{~h} \\
\text { in a unit at one time. }\end{array}$ \\
\hline 3 & 890 & 180 & $\underset{85.0}{\geq}$ & $\leq 2.21$ & $\leq 0.93$ & 650 & 305 & $\begin{array}{c}2012-7 \text { to } 2014-12, \# 1 \\
6769.96 ; \\
2012-12 \text { to } 2014-12 \\
\# 214496.51\end{array}$ & 无 \\
\hline 4 & $1335 / 1366$ & $175 / 165$ & $\begin{array}{c}81.5 / 83 \\
.0\end{array}$ & $1.32 / 1.45$ & $\begin{array}{c}0.72 / \\
0.72\end{array}$ & $720 / 736$ & $380 / 380$ & - & $\begin{array}{l}\text { The SCRexit operation period is } 2 \mathrm{~h} \\
\text { in a unit at one time as the obstraction } \\
\text { of flame arrester in the transporting } \\
\text { ammonia pipeline in } 1 \# \text { unit in } 2013 \text {. } \\
\text { The SCRexit operation period is } 1 \mathrm{~h} \\
\text { in a unit at one time as the fault of the } \\
\text { liquid ammonia Control Valve in } \\
\text { 1\#unit in } 2014 \text {. }\end{array}$ \\
\hline 5 & $\begin{array}{c}523 / 580 / \\
623 / 630\end{array}$ & $\begin{array}{l}120 / 136 / \\
130 / 133\end{array}$ & $\underset{75.0}{\geq}$ & $\begin{array}{l}1.01 / 1.3 / \\
1.65 / 1.61\end{array}$ & $\leq 1.0$ & $\begin{array}{c}539 / 510 / \\
505 / 530\end{array}$ & 310 & 0 & 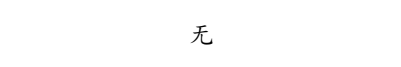 \\
\hline 6 & 330 & 80 & $\begin{array}{c}\geq \\
80.0\end{array}$ & $\leq 3$ & $\leq 1.0$ & 360 & 300 & $\begin{array}{c}\text { 2013-6 to } 2014-12, \# 7 \\
\text { 1523.83; } \\
\text { 2013-6 to } 2014-12, \# 8 \\
2184.48 ; \\
\text { 2013-12 to } 2014-12, \\
\quad \# 9610.31 ; \\
2013-12 \text { to } 2014-12, \\
\# 10772.42 ; \\
2013-3 \text { to } 2014-12, \# 12 \\
1974\end{array}$ & 无 \\
\hline 7 & 550 & 100 & $\begin{array}{l}\geq 2.0 \\
82.0\end{array}$ & $\leq 3$ & $\leq 1.0$ & 30 & 315 & 0 & $\begin{array}{l}\text { The SCRexit operation period is } \\
35.4 \mathrm{~h} \text { in a unit at two times as the } \\
\text { fault of the mixer of the ammonia and } \\
\text { air in } 3 \# \text { unit in } 2014 \text {. } \\
\text { The SCRexit operation period is } \\
26.8 \mathrm{~h} \text { in a unit at one time as the } \\
\text { blocking air preheater in } 3 \# \text { unit } \\
\text { in } 2015 \text {. } \\
\text { The SCRexit operation period is } 3.3 \mathrm{~h} \\
\text { in a unit at one time as the leakage of } \\
\text { the spray ammonia valve in } 4 \# \text { unit } \\
\text { in } 2014 \text {. } \\
\text { The SCRexit operation period is } \\
2.17 \mathrm{~h} \text { in a unit at two times as the } \\
\text { blocking diluting wind flowmeter in } \\
\text { 2\#unit in2014. } \\
\text { The SCRexit operation period is } \\
\text { 12.08h in a unit at two times as the } \\
\text { blockage of the mixer of the } \\
\text { ammonia and air diluting wind } \\
\text { flowmeter in } 4 \# \text { unit in } 2014 \text {. }\end{array}$ \\
\hline 8 & - & - & $\begin{array}{c}85.0 / 84 \\
.0\end{array}$ & - & / & / & 750 & 0 & 无 \\
\hline 9 & 350 & 180 & $\underset{70.0}{\geq}$ & $\leq 10$ & / & / & - & 0 & 无 \\
\hline 10 & - & - & $\underset{70.0}{\geq}$ & $0.97 / 1.02$ & I & I & 760 & 0 & 无 \\
\hline
\end{tabular}




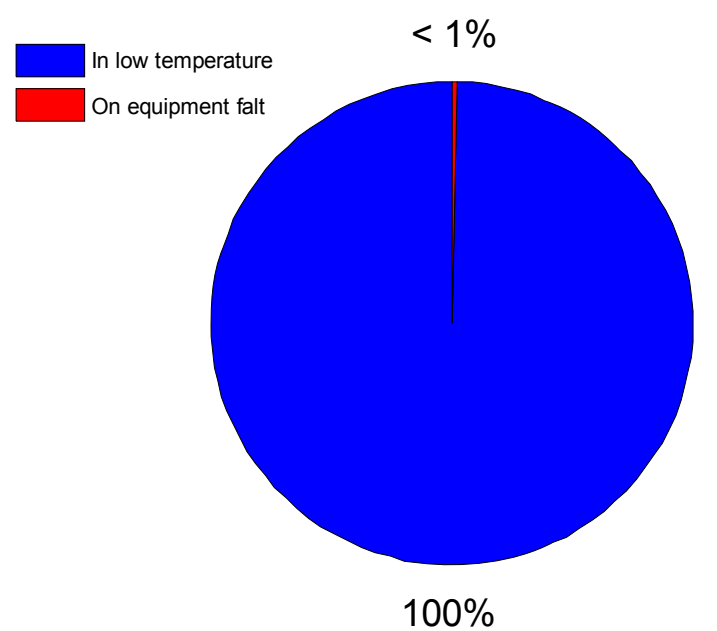

Fig.2 The distribution of the SCR device in exit operation

\section{The Conclusions and recommendation}

(1) In a province in Southern China,the SCR technology is mainly utilized in denitration facilities of the Coal-fired power plants while the SNCR technology is used for the circulating fluidized bed units.

(2) comparing the two kinds of denitrification devices, the reliability of SNCR technology is very high but the denitrification rate is lower, which is only suitable for the circulating fluidized bed boilers.

(3) The time of the SCR denitration facilities annealing operation in low temperature under lower load is longer that accounts for $99.7 \%$ of the total in units, which is the main problem for the SCR technology. The recommendation on the transformation of the boiler heating surface to improve the load adaptability for the SCR denitrification system.

\section{References}

[1] The federation of electric power enterprises in china. The list of basic data for electric power statistics in 2012[R],2012.

[2] Dejing Che,Jie Meng,Yonghui Chen,etal.The forecast analysis of water consumption for fire power generation in national for the 20 years[J].Electric power construction,2013,34(8):17-21.

[3] National Environmental Status Bulletin in 2011..

[4] The Ministry of environmental protection in the people's Republic of China.Outline of the 12th Five Year Plan for national economic and social development [R],in2011.

[5] Zuhui Peng.The analysis on the running status of the coal - fired units in Jiangsu Province[J]. Electrical Engineering in Jiangsu Province, 2013,32(6):77-80.

[6] Jianxun Dong,Bing Yan,Zonglin Zhao,Songling Wang,Zhaoxing Feng ,etal.Analysis of influence of flue gas denitrification device on boiler operation[J].Thermal power generation, 2007(3):17-18,23.

[7] Jianming Chen,Aibing Fan.Pollution status of nitrogen oxides in thermal power plant of Jiangsu province and Its Countermeasures[J]. Electrical Engineering in Jiangsu Province, 2008, 27(5): 23-26.

[8] Huaixiang Huang,Chuanhe Duan.Selective catalytic reduction (SCR) flue gas denitrification [M].Beijing:Chinese Electric Power Press,2015(4):44-45. 